\title{
EFFECT OF MUSIC EXPOSURE ON THE WEIGHT AND BODY-LENGTH OF RAT-LITTERS
}

\author{
Ria Puspitawati \\ Department of Oral Biology Faculty of Dentistry University of Indonesia
}

\begin{abstract}
Music is related to stress reduction and increased levels of growth-hormone. In rat, music exposure since Izatal period was found to increase body-weight of 7 -days-old litters and brain cells. Somatic growth was Trmarily influenced by growth-hormone and supported by psycho-physic condition. The objective of this Th was to analyze whether music exposure since prenatal until 35 days post-natal period could affect the -enght and body-length of the rat-pups. Four pregnant Wistar rats were daily exposed to one hour classic music (Mozart) every 17.30 PM since gestation period day one until the 22 litters were 35-days-old. Controls - 5 pregnant rats and their 36 litters caged in a different room with no music. Weighing and measuring the sot -length (the most anterior point of nasal-septum to the base of the tail) were conducted at day 7,25 and I5 Data were analyzed using Multivariate General-Linear-Model $(\alpha=0.05)$. It was revealed that the mean - $=1$ ght of the experimental litters was significantly higher than those of the controls either at day $7(p=0.00)$, $\because$ or $35(p=0.006)$. Difference of the body-length of the experiment and control animals only significant at $2 x$ : $25(p=0.012)$. Conclusion: Music exposure since prenatal period has significant influences on the weight $\because \because$ the rat-litters aged 7,25 and 35 days and on the body-length of the 25-days-old litters. Indonesian Journal $\because$ Dentistry 2006; Edisi Khusus KPPIKG XIV:325-328
\end{abstract}

Sis words: growth-hormone, music, rat

\section{Introduction}

In recent years it has been widely accepted that zertain types of music could arise various positive swlogical effects either in human, plants, or nomals. In human, music is capable of affecting sological condition through 'mind-bodyinnection' mechanism. ${ }^{1}$ Many clinical studies had soown that music could influence respiration and reart rate, body temperature, blood-pressure and Todulation of hormonal concentration ${ }^{2}$. Listening to rusic could lead to decreased levels of cortisol and zpinephrine and increased levels of prolactin and ondorphin. ${ }^{2,3}$ One study in human reported that seyboard or drum exercise lead to increased growth hormone $(\mathrm{GH})$ level. $^{2}$ Similar effect was found in the healthy subjects exposed to techno music. ${ }^{4}$

In plants classic music by Bach and traditional music from India could stimulate com, marigold, zinnia and petunia to have more flowers ${ }^{2}$ while classic music modified with sounds of nature were related to the increment of polyamine and oxygen absorbed by Chinese cabbage and cucumber. ${ }^{s}$ Accordingly cattle exposed to Mozart's music ${ }^{2}$ or Johan Straus's Blue Danube ${ }^{6}$ was reported to produce more milk.

In 1993 Rauscher reported that students exposed to Mozart's sonata for two pianos in D major for 10 minutes performed better spatial ability compared to those exposed to new age music or those with no 
music. ${ }^{2,7}$ In relevance with this finding it was found that the same sonata given daily to rats resulted in significantly increased brain cells and expression of brain-derived-neurotrophic-factor (BDNF) and synapsin-1 (protein of synaptic growth). ${ }^{7}$ Another study found that daily exposure of a number of Mozart's classic compositions on pregnant rats caused higher amount of brain cells of the litters compared to those delivered from the rat-mothers which had no music. ${ }^{8}$ It has been postulated that music could affect intelligence and creativity by increasing the amount, complexity and coordination of brain cells and functional synaps., ${ }^{2,8}$ These findings also indicating that music exposure has a potency in increasing somatic growth. Puspitawati et al. had proved that music exposure since prenatal period is significantly related to body weight of 7 days old rat-litters. ${ }^{9}$

Growth is a continuous process that begins before birth and refers to increase in physical size. Since growth is a result of function of all body systems, clinically it most frequently concerned with weight, height and head circumference. Because it involves all the increment of increase in size weight is often considered as a good index of growth in general while height is usually refer to skeletal growth. $^{10}$

Besides genetics and adequate diet, other factors that strongly affect growth are absence of stress and modulation of a number of hormones. In times of stress, adrenal cortex releases cortisol. Cortisol is known to have significant catabolic antigrowth effects. Conversely, growth hormone (GH) together with Insulin-]ike-growth-factors (IGFs) is metabolically anabolic for proteins, directing energy and amino acids into protein synthesis, which is an essential part of tissue growth. Although $\mathrm{GH}$ is released throughout life but its biggest role is during childhood. Severe GH deficiency in childhood could lead to dwarfism."

Studying previous findings that music exposures in rat could increased growth of brain tissue and body weight of 7 - days old pups, and in human have influence on emotional states, stress relieve and modulation of hormonal concentration including $\mathrm{GH}$, and considering that body weight and height are common indicators of somatic growth which are significantly influenced by $\mathrm{GH}$, the objective of this second preliminary study was to examine whether daily exposures of classic music since prenatal period could affect the body weight and length of rat litters aged 7,25, and 35 days.

The empirical confirmation of the effect of music on somatic growth might be beneficial in promoting the growth and the quality of the whole body and its organs. Now that the role of GH in odontogenesis becoming further discovered, empirical findings showing the relationship of music, somatic growth, and GH may give light to the possibility of utilizing music to increase the growth and/ or quality of the dentition.

\section{Methods}

Ten female Wistar rats aged 120 days were randomly grouped into experiments and controls. The two groups were caged in two separate rooms and fed standard diet ad libitum. Since a week before matting the 5 experiment rats were conditioned with daily 30 minutes music exposure. One rat was not becoming pregnant so only the remaining 4 rats were continuously given the daily 60 minutes music exposure since the first day of their gestation period until their litters were 7-daysold. Five control rats were kept in a same condition as those of the experimental rats but with no music.

Music exposure was given by playing a set of cassettes containing 8 selected numbers of classic music composed by Mozart. Music was played every day at 17.30 PM. Twenty-two experiment and 36 control litters were weighed using a manual triple beam balance (Ohaus capacity 26l0gr), and their body-length (the most anterior point of nasal septum to the base of the tail in animals lying ftat on their stomach) were measured using a caliper at day 7,25 , and 35 . The mean weights and body-lengths of the two groups were compared and analyzed using General linear model (GLM) Multivariate with significance level $95 \%(\alpha=0.05)$.

\section{Results}

To confirm that the general condition of the ratmothers in the two groups were equal and so the litters might have an equal opportunity to grow optimally, the comparison of their initial weight (weight at day 1 of gestation period), weight before partus, weight increment (the difference between weight before partus and initial weight) and number of litters were analyzed using Mann-Whitney test with significance level $95 \% / \alpha=0.05$.

As shown in table 1 , there were no statistical significant differences between the mothers of the control and the experiment groups either for their initial weight $(P=0.221>0.05)$, weight before 
$\approx P=0.389>0.05)$, weight increment $(P=$ Ars $>05$ i or number of litters $(P=0.169>0.05)$.

Ian : Weght at Day 1 and Last Day of Gestation Period. Weight Increment and Number of Litters of the Rat-Mothers

\begin{tabular}{|c|c|c|c|c|c|}
\hline in Facke & Group & $\mathrm{N}$ & Mean & SD & $\dot{\mathrm{P}}$ \\
\hline \multirow{2}{*}{ 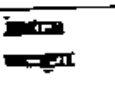 } & Conuol & 5 & $158.56 \mathrm{gr}$ & 19.79 & 0.221 \\
\hline & Experiment & 4 & $140.23 \mathrm{gr}$ & 11.31 & \\
\hline \multirow{2}{*}{ 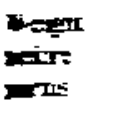 } & Control & 5 & $212.22 \mathrm{gr}$ & 16.53 & 0.389 \\
\hline & Experiment & 4 & $198.95 \mathrm{gr}$ & 20.91 & \\
\hline \multirow{2}{*}{ 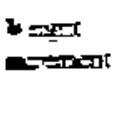 } & Control & 5 & $53.66 \mathrm{gr}$ & 6.32 & 0.806 \\
\hline & Experiment & 4 & $53.82 \mathrm{gr}$ & 8.93 & \\
\hline \multirow{2}{*}{ 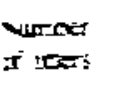 } & Control & 5 & 7.20 rats & 1.30 & 0.169 \\
\hline & Experiment & 4 & $5.75 \mathrm{rats}$ & 1.71 & \\
\hline
\end{tabular}

$\rightarrow: P=0.389>0.05)$, weight increment $(P=$ I $>0.05)$ or number of litters $(P=0.169>0.05)$.

ice = Mean Weight and Body-Length of Rat Litters with and without Music With Sex as a Covariate.

\begin{tabular}{|c|c|c|c|c|}
\hline : rnable & $\begin{array}{c}\text { Mean (gr) } \\
\pm \mathrm{SD} \text { in } \\
\text { gr } \\
\text { (Controls) }\end{array}$ & $\begin{array}{c}\text { Mean (mm) } \\
\pm \text { SD } \\
\text { (Experi- } \\
\text { mental) }\end{array}$ & $\begin{array}{c}\mathrm{P} \\
\text { Value }\end{array}$ & $\begin{array}{c}P \\
\text { Value } \\
\text { for } \\
\text { Sex }\end{array}$ \\
\hline $\begin{array}{l}50 ? \text { neight } \\
\text { I = : }\end{array}$ & $\begin{array}{c}11.664 \pm \\
1.171\end{array}$ & $\begin{array}{c}13.192 \pm \\
0.729\end{array}$ & .00 & .313 \\
\hline $\begin{array}{l}5 \therefore \text { weight } \\
\text { II }=35\end{array}$ & $\begin{array}{c}38.204 \pm \\
4.409\end{array}$ & $\begin{array}{c}42.192 \pm \\
3.245\end{array}$ & .006 & .472 \\
\hline $\begin{array}{l}\equiv-3 \text { weight } \\
x \geq 35\end{array}$ & $\begin{array}{c}64.889 \pm \\
6.550\end{array}$ & $\begin{array}{c}70.923 \pm \\
4.408\end{array}$ & .006 & .585 \\
\hline 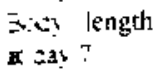 & $\begin{array}{c}6.529 \pm \\
0.320\end{array}$ & $\begin{array}{c}6.585 \pm \\
0.248\end{array}$ & .651 & .221 \\
\hline 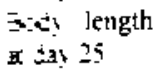 & $\begin{array}{c}9.931 \pm \\
0.646\end{array}$ & $\begin{array}{c}10.492 \pm \\
0.545\end{array}$ & .012 & .883 \\
\hline $\begin{array}{l}\text { Eity length } \\
\mathrm{x} \text {-3. } 35\end{array}$ & $\begin{array}{c}12.327 \pm \\
0.688\end{array}$ & $\begin{array}{c}12.577 \pm \\
0.939\end{array}$ & .358 & .992 \\
\hline
\end{tabular}

Statistical analysis showed that sex is not ::enificantly related to weight and body length of the -:-imals $(\mathrm{p}>0.05)$. Therefore in analysing the data $=$ this study, the variable sex could be ignored. $P$ - alue for differences in body weight between control $35 d$ experimental animals were 0.00 ( 7 days old) and $\because 006$ (25 and 35 days old) $<0.05$. This confirmed that music exposure given to the experimental anımals was significantly related to their body weight. Conversely, only body-length at day 25 was significantly different between experimental and control animals $(p=0.012<0.05)$.

\section{Discussion}

It has become apparent that different types of music induce different neuroendocrine changes. In human, personal experiences and temperament may influence the wide inter-individual variability in response to music ${ }^{4}$. The present study used laboratory animals so that such subjective variability in response to music could be controlled.

Positive biological effects could be gained by using various types of music. However one among several types of music that has been mostly investigated in relation with its positive biological effects $^{2}$ and had been found to be associated with increased body weight ${ }^{9}$ and growth of brain tissue in rats ${ }^{7.8}$ is classic music composed by Mozart. This was the consideration when deciding to use Mozart's composition in this study.

This study showed that the weight of the ratlitters exposed to music was significantly higher than those with no music either at day 7,25 or 35 days. This result is in relevance with previous studies that music could evoke a positive biological effect and supports a hypothesis that positive biological response stimulated by music may lead to increased somatic growth.

There are some possibilities of the physiological mechanisms underlying the results of this study. This could be supported by the results of previous studies in which music exposure were related to increased concentration of prolactin in human or increased milk production in cattle ${ }^{2}$. In this study music exposure was given since prenatal period, therefore it might resulted in the increment of prolactin which is essential in stimulating milk production of the rat-mothers which in turn would optimizing the growth of the litters.

In human music is a powerful tool in evoking emotions. Listening to music can be effective in reducing the negative effects of stress ${ }^{3}$. It has been accepted too that there is a link between the mind and the body. According to this neuroimmunomodulation model there is a strong bi-directional relationship between psyche, nervous, endocrine and immune systems. Therefore anything affecting one of those four systems would stimulate response in others. Physical or emotional stress could lead to disturbed homeostasis and results in aiteration of immunoneuroendocrine functions. Conversely, absence of stress would lead to increased immune 
system and better homeostasis ${ }^{11}$. Even though there was not any reports on the effect of music to emotional state or to hormonal concentration in rat but the finding that music exposure could increase milk production of cattle lead to a hypothesis that calming music could reduce stress in animals just as it does in human".

For normal growth to take place $\mathrm{GH}$ is required throughout life particularly in childhood. The overall effect of $\mathrm{GH}$ is to promote somatic growth ${ }^{9,12}$. An index universally used to measure growth especially in the early years of life is body weight. Therefore, body weight could be presumed as an indicator of the extent of $\mathrm{GH}$ effect on the somatic growth, and thus the higher body weight of rat-litters exposed to music compared to those without music in this study might be an indicator of the increased concentration of $\mathrm{GH}$ in those animals.

The most striking and obvious effect of $\mathrm{GH}$ is in stimulating linear growth of the skeleton and growth of a number of tissues in the body. Growth hormone holds prominent role in remodeling, regulation of bone mass and postnatal longitudinal growth. ${ }^{13}$ Therefore significant increased of $\mathrm{GH}$ may lead to significant increased in long bones which further results in increased body-length. In this study it was found that the body length of rat litters exposed to music was higher than those without music even though these differences only significant at day 25 . The explanation of this finding may be related to the various accelerated-growth phase at certain ages during organism's lifetime. ${ }^{10}$ Rats reach their pubertal period at 50 days-old ${ }^{14}$, so that at 25 -days old they might be analog with the first 2 years of human life where the active phase of somatic growth is at its peak.

\section{Conclusion}

This study showed that body weight of Wistar rat litters aged 7,25 and 35 days was strongly associated with the daily exposures of one-hour Mozart's classic music given since prenatal period. Similarly, the body length of the animals was also affected by the given music exposure although the significance of this effect is influenced by the age of the animals. Some possible physiological mechanisms underlying this phenomenon are as follows; 1) Music exposure since prenatal period lead to increased secretion of prolactin in the ratmothers so that the litters could get more milk, 2)
Music exposure lead to reduced stress either in ratmothers or in the litters and thus lead to a better immune system and homeostasis, 3) Similar to the previous studies in human, music exposure given to the rat-mothers and their litters resulted in increased concentration of $\mathrm{GH}$.

The positive effect of music in stimulating somatic growth by using body weight and body length as parameters as shown by this study brings a responsibility to further investigating the mechanism of effect of music on stimulating somatic growth in cellular and molecular levels so that the application of music might be further optimized to increase the quality of body health and its organs including the dentition.

\section{References}

I. Briluman B. Music Making: Practical Tuning Insights. www. Healt l:RIIYTHMS-Remolnc. 12 Maret, 2000

2. Campbeil D. Ejek Mozart. Memanfaatkan Kekatan Musik untuk Mempertajam Pikiran. Monungkatkan Kreativitas an Menyehutkan Tutuh. Jakarta; Gramedia Pustaka Utama. 2001

3 Khalf S Bella SD Roy M Peretz I Lupien SJ. Effects of Relaxing Music on Salivary Cortisol Level after Psychological Stress. Ann N Y Acad Sci 2003; 999; 374-6

4. Gerra G, Zainovic A, Franchini D, Palladino M, Giucastro G, Reali $N$ Marstri D, Caccavari $R$ et al. Neuroendocrine Response of Healthy Volunteers to "Techno-music": Relationship with Healthy Volunteers lo Techno-music: Relationship witity Traits and Emotional State. Int I Pycophysiol 1998; 28(1);99.111.

5. Qin YC, Lee WC, Choi YC, Kin TW. Biochemical and Physiological Changes in Plants as a Result of Different Sonic Exposures. Utraxonics 2003 ; July I; 4(5); 407-I!.

6. Briggs H. Sweet music for milking. Organic Consumers Association

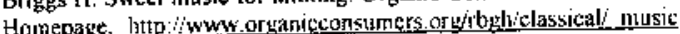
wilk production.cfin. Diakses tanggal 26 May 2003.

7. Ratscher F, and $\mathrm{Li} \mathrm{HH}$. Molecular Basis for Mozart Effect Revealed. New \$cientist Com. Inttpi/www.newscientist.com/newst print. Diakses tanggal 23 April 2004

8 . Estoepangestie ATS, Widjati. The Influence of Musical Exposure to Pregnant Rats (Ratms novergicts) to the Anount of Neonatal Rat Brain Cells. Periemian Hmiah Tahunan Fetomaternat, Steraton Hotel Surabaya Indonesia. 27-30 Maret 2002 .

9. Puspitawati R, Suniani DF, Auerkari EI., Suglano RH. The Relationship of Music Exposure since Prenatal Period and the BodyWeight. The Intemationat Metung Dentstry for Namo-Informatic

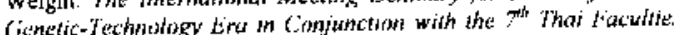
Board Screntific Meting. Sofited Raja Orchid Holel. Kohn Kaen, Thailand. 2-4 February 2005.

10. Forrester DJ, Wagner ML, Fleming J. Plysical Growth and Development: Normal and Aberant Patterns in Pedotric lentat Medicine. Philadelphia: Lea and Fabiger. 1981; 11-7.

11. Silverthom DU, Ober WC, Gartisan CW, Silverton AC. Endocrine Control of Growth in Human Physistogy. An integrated Approach $2^{\text {thd }}$ ed. New Jersey: Prentice Hall, 2001: 672-3, 709-11.

12. Rhoades R, Pflanzer R. The Piluitary Hormone in Humom Physiology $3^{\text {tat }}$ ed. Fort Wortl: Saunders College Publishing. 1996; 408.9.

13. Olilsson C, Bengisson BA, Isakson OGP, Andreassen TT, Siootweg. MC. Growth Hormone and Bone. Endocrme reviews. 1998: 19 (1) 55-79.

14. Fartis EJ, Gritfith JQ. The Rat in Ilaboratory Investigation. $2^{\text {InI }}$ ed Philadelplua: JB Lippincott Co. 194 